\title{
ANALISIS EFISIENSI TEKNIS USAHATANI KEDELAI (Glycine max (L) merril) DI DESA MARGALUYU KECAMATAN PANCATENGAH KABUPATEN TASIKMALAYA
}

\author{
RINI NURAINI $^{1 *}$, TRISNA INSAN NOOR ${ }^{2}$, AGUS YUNIAWAN ISYANTO ${ }^{1}$ \\ ${ }^{1}$ Fakultas Pertanian Universitas Galuh \\ ${ }^{2}$ Fakultas Pertanian Universitas Padjajaran \\ *E-mail: nurainir123@gmail.com
}

\begin{abstract}
ABSTRAK
Tujuan penelitian ini adalah untuk menganalisis: (1) Faktor-faktor yang mempengaruhi produksi (2) Tingkat efisiensi teknis pada usahatani kedelai, dan (3) Faktor-faktor yang berpengaruh terhadap inefisiensi teknis pada usahatani kedelai di Desa Margaluyu Kecamatan Pancatengah, Kabupaten Tasikmalaya. Sampel yang diambil sebanyak 31 orang dari populaasi 124 orang dengan menggunakan metode purposive sampling, di analisis menggunakan model fungsi Stochastic Frontier Model, koefisien regresi dihitung menggunakan metode Maximum Likelihood Estimation (MLE). Hasil penelitian menunjukkan bahwa (1) Ukuran lahan, pestisida dan tenaga kerja merupakan variabel yang sangat mempengaruhi peningkatan produksi kedelai (2) Rata-rata tingkat efisiensi teknis input yang digunakan adalah 95,8\% dari potensi produksi maksimum yang akan didapatkan, dan (3) Umur, pendidikan dan ukuran keluarga petani merupakan faktor yang tidak berpengaruh nyata terhadap ketidak efisiensian usaha teknis untuk meningkatkan produksi kedelai.
\end{abstract}

Kata Kunci: Efisiensi teknis, stochastic frontier fungsi produksi, usahatani kedelai

\section{ABSTRACT}

This study aims to analyze (1) the factors that influence production (2) the level of technical efficiency achieved in soybean farming, and (3) the factors that influence technical inefficiency in soybean farming in Margaluyu Village, Pancatengah District, Tasikmalaya Regency. Samples were taken as many as 31 people from a population of 124 people using purposive sampling method, analyzed using the Stochastic Frontier Model function model, the regression coefficient was calculated using the Maximum Likelihood Estimation (MLE) method. The results showed that (1) the size of land, pesticides and labor were variables that greatly influenced the increase in soybean production (2) The average level of technical efficiency of the inputs used was $95.8 \%$ of the maximum potential production to be obtained, and (3) Age, education and size of the farmer's family are factors that do not significantly affect the inefficiency of technical efforts to increase soybean production.

Kewords: Technical efficiency, stochastic frontier production function, soybean farming

\section{PENDAHULUAN}

Tercapainya efisiensi usahatani dapat diukur melalui perhitungan efisiensi teknis. Konsep efisiensi teknis didasarkan asumsi bahwa sumber daya untuk memenuhi kebutuhan hidup manusia terbatas, sehingga mendorong manusia untuk memenuhi kebutuhannya dengan menghasilkan suatu output secara maksimal. Hal ini sejalan dengan efisiensi berkaitan dengan pencapaian output maksimal dari alokasi sejumlah sumber daya atau output.

$$
\text { Kedelai (Glycine } \max \text { L) adalah }
$$
komoditas utama kacang-kacangan yang menjadi andalan nasional karena 
merupakan sumber protein nabati penting untuk diversifikasi pangan dalam mendukung ketahanan pangan nasional.

Desa Margaluyu memiliki produktivitas tertinggi usahatani kedelai di Kecamatan Pancatengah. Produktivitas yang tinggi ini diduga juga memiliki tingkat efisiensi teknis yang tinggi pula. Atau dengan kata lain, petani kedelai di Desa Margaluyu Kecamatan Pancatengah telah mencapai efisien secara teknis. Hasil penelitian ini diharapkan menjadi model bagi usahatani kedelai di Kabupatn Tasikmalaya. Berdasarkan uraian di atas, maka dilaksanakan penelitian ini yang berjudul Analisis Efisiensi Teknis Usahatani Kedelai (Glycine max (l) merril) di Desa Margaluyu Kecamatan Pancatengah Kabupaten Tasikmlaya.

Peenelitian ini bertujuan untuk menganalisis:

1. Faktor-faktor yang mempengaruhi produksi pada usahatani kedelai di Desa Margaluyu Kecamatan Pancatengah Kabupaten Tasikmalaya.

2. Tingkat efisiensi teknis pada usahatani kedelai di Desa Margaluyu Kecamatan Pancatengah Kabupaten Tasikmalaya.

3. Faktor-faktor yang berpengaruh terhadap inefisiensi teknis pada usahatani kedelai di Desa Margaluyu
Kecamatan Pancatengah Kabupaten

Tasikmalaya.

\section{METODE PENELITIAN \\ Jenis Penelitian}

Jenis penelitian ini menggunakan penelitian kuantitatif. Menurut Sugiyono (2016), metode penelitian kuantitatif adalah metode penelitian yang digunakan untuk meneliti pada populasi atau sampel tertentu, teknik pengambilan sempel pada umumnya dilakukan secara random, pengumpulan data menggunakan instrument penelitian, analisis data bersifat kuantitatif/statistik dengan tujuan untuk menguji hipotesis yang telah ditetapkan. Penelitian kuantitatif menghasilkan data numerikal/angka yang dapat menjadi kesimpilan dari penelitian yang dilakukan.

\section{Teknik Pengumpulan Data}

Teknik pengumpulan data dalam penelitian ini menggunakan data primer dan data sekunder. Data primer di peroleh melalui wawancara langsung ke petani dan data sekunder di peroleh dari lembaga penyedia informasi seperti dinas ataupun intansi terkait dengan penelitian.

\section{Teknik Penarikan Sampel}

Lokasi penelitian diambil secara purposive sampling dengan alasan karena Kelompok Tani yang ada di Desa Margaluyu Kecamatan Pancatengah Kabupaten Tasikmalaya merupakan 
kelompok tani yang sangat berpotensi dalam usahatani kedelai dan memiliki luas panen paling tinggi di Kecamatan Pancatengah. Menurut Nasehudin dan Gozali (2012), purposive sampling berarti sampel yang diambil tidak acak atau secara sengaja dengan sengaja di pilih atas pertimbangan tertentu.

Penarikan sampel dilakukan dengan pertimbangan apabila jumlah populasinya kurang dari 100 orang, maka jumlah sampelnya diambil secara keseluruhan; tetapi jika populasinya lebih besar dari 100 orang, maka bisa diambil 10-15\% atau $2025 \%$ dari jumlah populasinya (Arikunto, 2006). Populasi yang menjadi objek penelitian ini adalah 124 orang. Jumlah sampel yang diambil dari populasi tersebut sebanyak $25 \%$ sehingga jumlah sampel sebanyak 31 orang.

\section{Rancangan Analisis Data}

Efisiensi teknis menggunakan anlisis frontier, atau model stocholstic production frontier (SPF). Fungsi ini pertanma kali diperkenalkan oleh Aigner et al. (1977); serta Meeusen dan Van Den Broek (1977). Pengembangan pada tahuntahun berikutnya banyak dilakukan seperti oleh Battese dan Coelli (1992, 1995).

Model persamaan yang digunakan untuk menduga estimasi dari fungsi produksi Cobb-Douglas dengan pendekatan stochastic frontier dalam penelitian ini adalah sebagi berikut:

$\operatorname{Ln} y=\beta o+\ln \beta 1 X 1+\beta 2 \ln X 2+\beta 3 \ln$ $\mathrm{X} 3+\beta 4 \quad \ln \mathrm{X} 4+$ (viui).

Keterangan:

$\mathrm{Y}=$ produksi

$\beta=$ koefisien regresi (koefisien parameter yang ditaksir) (i=1 s/d 7)

$\mathrm{X}_{1}=$ benih $(\mathrm{kg})$

$\mathrm{X}_{2}=\operatorname{pupuk}(\mathrm{kg})$

$\mathrm{X}_{3}=$ tenaga kerja $(\mathrm{HOK})$

$\mathrm{X}_{4}=$ pestisida $(\mathrm{l})$

vi - ui $=$ error term (ui ) efek inefisiensi dalam model.

Error term, model stochastic frontier disebut juga dengan model composed error terdiri atas:

$$
\mathrm{Ci}=\mathrm{vi}-\mathrm{ui} \mathrm{I}=1,2, . ., \mathrm{n} .
$$

Komponen error yang pertama vi adalah error karena faktor ekternal yang diasumsikan mengikuti distribusai normal simetris (vi $\approx 0, \sigma 2$ ). Sedangkan komponen error yang kedua u adalah error karena faktor internal yang dapat dikendalikan oleh petani dan menggambarkan kemampuan manajerial petani. Komponen ini diasumsikan berdistribusi asimetris (ui > 0) atau setengah distribusi niormal (ui $\approx \mathrm{N}(0, \sigma 2$ ). Apabila proses produksi sepenuhnya efisien, maka produksi yang dicapai sama 
dengan potensinya atau ui $=0$, sebaliknya apabila produksi yang dicapai di bawah potensinya, maka ui $>0$.

Penentuan nilai efisiensi teknis didasarkan pada pendapat Jondrow et al (1982), mengestimasi tingkat efisiensi teknis/technical efficiency (TE) sebagai berikut:

$\mathrm{TE}=\exp (-\mathrm{E}[\mathrm{ui} / \mathrm{Ei}])$

dengan $\mathrm{E}[\mathrm{ui} / \mathrm{Ei}]=\frac{\sigma_{u \sigma v}}{\sigma}\left[\frac{f\left(\frac{\epsilon i \lambda}{\sigma}\right)}{1-f\left(\frac{\epsilon i \lambda}{\sigma}\right)}-\right.$ $\left.\left(\frac{\varepsilon i \lambda}{\sigma}\right)\right]$

di mana $\lambda=\sigma \mathrm{u} / \sigma \mathrm{v}, \sigma 2=\sigma \mathrm{u} 2+\sigma \mathrm{v}$ Sedangkan $f$ dan $F$ masing masing menunjukkan fungsi densitas standar normal dan fungsi distribusi kumulatif standart normal yang dihitung dari $€ i \lambda$.

$$
\text { Inefisiensi teknis dihitung }
$$

menggunakan model sebagai berikut:

$\mathrm{Ui}=\delta \mathrm{o}+\delta 1 \mathrm{z} 1+\delta 2 \mathrm{z} 2+\delta 3 \mathrm{z} 3+\delta 4$ $\mathrm{z} 4$.

Keterangan: Ui adalah inefisiensi produksi yang dicapai oleh petani ke-i, sementara z1-z4 berturut-turut adalah pendidikan petani, pengalaman berusahatani, usia petani, dan persepsi petani tentang perubahan iklim.

\section{Tempat dan Waktu Penelitian}

Lokasi penelitian dipilih secara sengaja yaitu di Desa Margaluyu Kecamatan Pancatengah Kabupaten Tasikmalaya dengan pertimbangan bahwa di daerah ini merupakan sentra produksi kedelai yang ada di Kecamatan Pancatengah.

Penelitian ini dilaksanakan pada bulan Februari sampai Agustus 2020.

\section{HASIL DAN PEMBAHASAN}

\section{Analisis Fungsi Produksi Stchastic Frontier}

Model ini memiliki nilai parameter $\gamma$ sebesar 0.1290 yang menunjukkan bahwa 12,90 persen dari error term yang berada dalam fungsi produksi disebabkan oleh keberadaan inefisiensi teknis, sedangkan 87,1 persen disebabkan oleh variabel kesalahan acak seperti cuaca, hama dan sebagainya. Ini berarti model fungsi produkssi stochastic frontier yang diperoleh dapat menunjukkan adanya keberadaan inefisiensi teknis pada model. Model fungsi produksi stochastic frontier usahatani kedelai dapat dituliskan dalam persamaan sebagai berikut:

$\ln \mathrm{Y}=2,3400-0,0112 \ln \mathrm{X}_{1}+0,0866 \ln$ $X_{2}+0,013 \ln X_{3}+1,1636 \ln X_{4}-0,0116$ $\ln \mathrm{X}_{5}+\mathrm{vi}-$ ui. 
Tabel 1. Model Fungsi Produksi Cobb-Douglas Stochastic Frontier dengan Menggunakan Metode MLE

\begin{tabular}{llll}
\hline \multicolumn{1}{c}{ Variabel Input } & \multicolumn{1}{c}{ Koefisien } & \multicolumn{1}{c}{ Standard-error } & \multicolumn{1}{c}{ t-rasio } \\
\hline Intersep & 2,3400 & 0,1788 & 13,0873 \\
Lahan $\left(\mathrm{X}_{1}\right)$ & $-0,0112$ & 0,0044 & $-25,3345^{*}$ \\
Benih $\left(\mathrm{X}_{2}\right)$ & 0,0866 & 0,05195 & 1,66782 \\
Pupuk $\left(\mathrm{X}_{3}\right)$ & 0,0013 & 0,0067 & 0,1951 \\
Pestisida $\left(\mathrm{X}_{4}\right)$ & 1,1636 & 0,0467 & $24,9329^{*}$ \\
Tenaga Kerja $\left(\mathrm{X}_{5}\right)$ & 0,0116 & 0,0065 & $17,8422^{*}$ \\
\hline Sigma-squared & 0,0033 & 0,0183 & 1,8182 \\
Gamma & 0.1290 & 0,3138 & 0,4110 \\
Log Likelihood & $46,2720^{*}$ & & \\
function & & & \\
LR test of one side & $14,7503^{*}$ & & \\
\hline
\end{tabular}

Keterangan: * nyata pada 5\%

Sumber: Data Primer, 2020 (diolah)

Dari hasil pendugaan pada Tabel ditemukan bahwa variabel lahan berpengaruh nyata dan negatif terhadap produksi kedelai. Nilai elastisitas sebesar 0,0112 artinya, bahwa penambahan luas lahan sebesar satu persen akan menurunkann produksi kedelai sebesar 0,0112 persen

Penggunaan benih tidak berpengaruh nyata dan positif terhadap produksi kedelai, karena penggunaan benih di lokasi penelitian adalah benih unggul tetapi perlakuan benih tidak sesuai dengan panduan usahatani kedelai. Nilai koefisiennya sebesar 0,0866 artinya, dengan menambah jumlah penggunaan benih satu persen maka akan meningkatkan produksi sebesar 0,0866 persen.

Penggunaan pupuk tidak berpengaruh nyata dan positif terhadap produksi kedelai. Nilai elastisitas pupuk sebesar 0,0013 menunjukkan bahwa adanya penambahan pupuk sebesar satu persen akan meningkatkan produksi kedelai sebesar 0,0013 persen.

Penggunaan pestisida berpengaruh nyata dan positif terhadap produksi kedelai. Nilai elastisitas pestisida sebesar 1,1636, berarti bahwa peningkatan penggunaan pestisida sebesar satu persen akan meningkatkan produksi sebesar 1,1636 .

Variabel tenaga kerja berpengaruh nyata dan bernilai positif terhadap produksi kedelai. Nilai koefisien tenaga kerja sebesar 0,0116, hal ini menunjukkan bahwa setiap penambahan satu persen tenaga kerja maka akan meningkatkan produksi kedelai sebesar 0,0116 persen. 
Analisis Efisiensi dan Inefisiensi Teknis

Tabel 2. Sebaran Efisiensi Teknis Usahatani Kedelai Petani Responden di Desa Margaluyu Kecamatan Pancatengah

\begin{tabular}{lccc}
\hline \multicolumn{1}{c}{ Variabel } & Koefisien & Standard-error & t-rasio \\
\hline Intersep $\left({ }^{3} 0\right)$ & $-0,2007$ & 0,2341 & $-0,8573$ \\
Umur $\left(\mathrm{Z}_{1}\right)$ & 0,0489 & 0,0708 & 0,6906 \\
Pendidikan $\left(\mathrm{Z}_{2}\right)$ & $-0,0001$ & 0,0089 & $-0,0158$ \\
Pengalaman $\left(\mathrm{Z}_{3}\right)$ & $0,16708^{*}$ & 0,0608 & 2,7467 \\
Ukuran Keluarga & $-0,0147$ & 0,0101 & 1,4530 \\
$\left(\mathrm{Z}_{4}\right)$ & & & \\
\hline
\end{tabular}

Secara keseluruhan, semua petani telah efisien secara teknis. Nilai rata-rata efisiensi teknis yang dicapai petani responden sebesar 0,958 atau 95,8 persen dari produksi maksimum. Artinya, petani kedelai sudah cukup efisien namun masih terdapat peluang sebesar 5,2 persen untuk mencapai produksi maksimum. Tingkat efiisiensi yang tinggi mencerminkan keterampilan manajerial usahatani kedelai sudah baik dan memuaskan. Sementara di sisi lain, tingkat efisiensi teknis yang tinggi juga mencerminkan bahwa peluang untuk meningkatkan produksi menjadi kecil karena kesenjangan antara tingkat produksi yang telah dicapainnya dengan tingkat produksi maksimum yang dapat dicapai dengan sistem penggolahan terbaik (the best practice) cukup sempit. Dengan kata lain, agar dapat meningkatkan produktivitas secara nyata maka dibutuhkan inovasi teknologi yang lebih maju.
Tabel 3. Inefisiensi Teknis Fungsi Produksi Stochastic Frontier Usahatani Kedelai di Desa Margaluyu Kecamatan Pancatengah

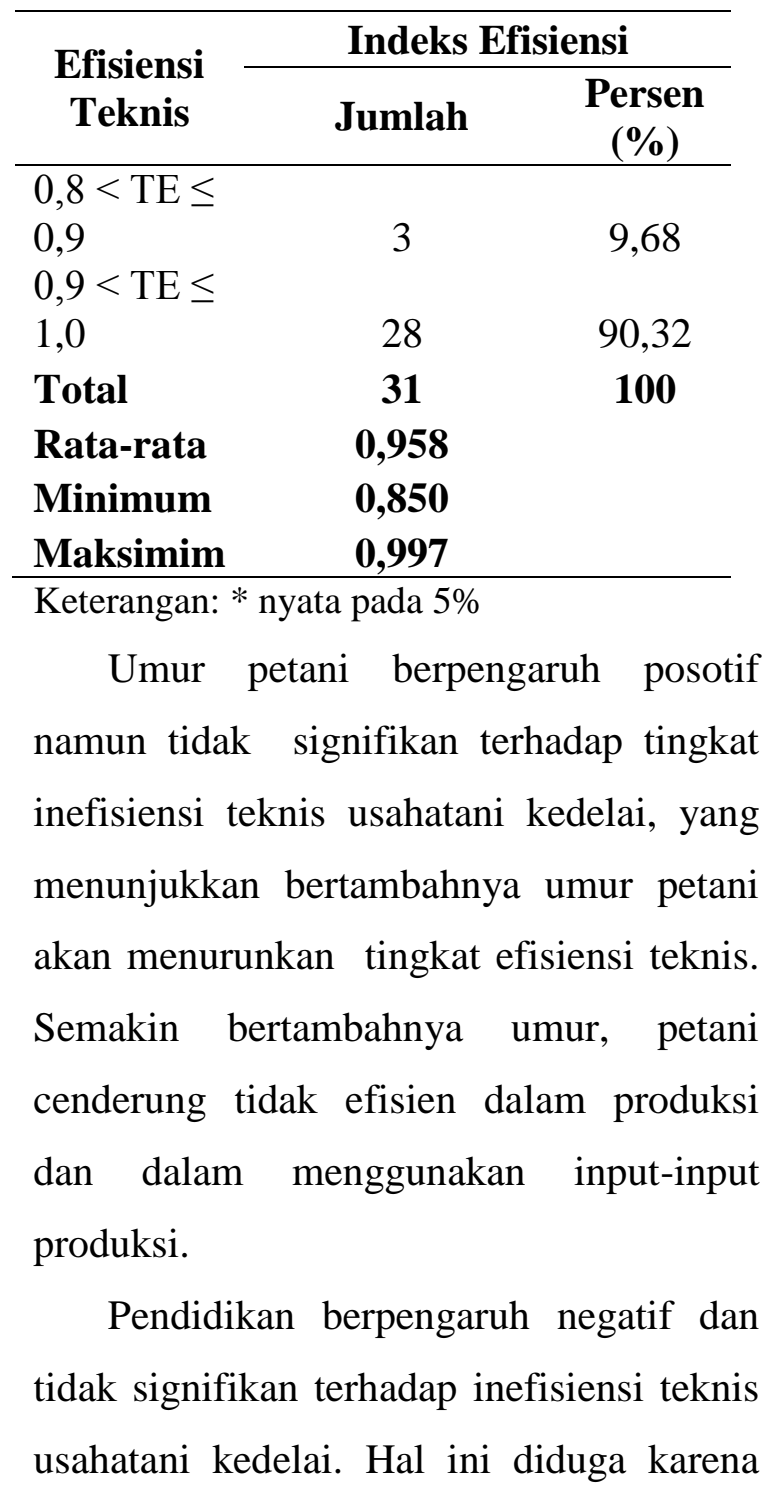


tingkat pendidikan para petani hampir seragam yaitu rata-rata hanya tamatan SD.

Pengalaman berpengaruh positif dan signifikan terhadap inefisiensi teknis usahatani kedelai. Kondisi ini menunjukkan bahwa variabel pengalaman akan meningkatkan efisiensi teknis usahatani kedelai. Semakin lama pengalaman petani dalam berusahatani kedelai, maka akan meningkatkan inefisiensi teknis dan akan menurunkan efisiensi usahatani kedelai.

Ukuran keluarga berpengaruh negatif dan tidak signifikan terhadap inefisiensi teknis usahatani kedelai. Petani yang memiliki jumlah ukuran keluarga yang besar akan mengalokasikan sebagian besar sumberdaya finansialnya untuk memenuhi kebutuhan pokok keluarganya, misalnya untuk pendidikan dan pangan.

\section{KESIMPULAN DAN SARAN Kesimpulan}

Berdasarkan hasil penelitian dan pembahasan, maka dapat ditarik beberapa kesimpulan sebagai berikut:

1. Penggunaan lahan, pestisida dan tenaga kerja berpengaruh nyata terhadap peningkaan produksi usahatani kedelai. Sementara faktor produksi lainnya seperti benih dan pupuk tidak berpengaruh nyata terhadap peningkatan produksi usahatani kedelai.
2. Secara keseluruhan, semua petani telah efisien secara teknis. Nilai rata-rata efisiensi teknis yang dicapai petani responden sebesar 0,958 atau 95,8 persen dari produktivitaas maksimum. Artinya, petani kedelai sudaah cukup efisien namun masih terdapat peluang sebesar 5,2 persen untuk mencapai produktivitas maksimum.

3. Faktor-faktor yang berpenaruh nyata terhadap inefisiensi teknis usahatani kedelai adalah pengalaman. Sedangkan umur, pendidikan dan ukuran keluarga tidak berpengaruh nyata terhadap inefisiensi teknis pada proses produksi kedelai.

\section{Saran}

Berdasarkan kesimpulan, maka diajukan beberapa saran sebagai berikut:

1. Tenaga kerja berpengaruh nyata terhadap produksi. Pengalaman berpengaruh nyata terhadap inefisiensi teknis, sedangkan pendidikan formal tidak berpengaruh nyata. Oleh karena itu, upaya peningkatan efisiensi bisa dilakukan melalui pendidikan non formal melalui kegiatan penyuluhan dan bimbingan teknis yang akan meningkatkan pengetahuan, keterampilan dan pengalaman petani.

2. Penelitian selanjutnya diharapkan menganalisis tingkat efisiensi alokatif dan 
ekonomis untuk mendapatkan analisis

efisiensi yang lebih komprehensif.

\section{DAFTAR PUSTAKA}

Arikunto, S. 2006. Prosedur Penelitian Suatu Pendekatan Praktek, Jakarta: Renika Cipta

Aigner, D.J, C.A.K.Lovell and P. Schmidt. 1977. Formulation and Estimation of Stochastic Frontier Production Function Models. Journal of Econometrics, 6(1):21-37

Bettese, G.E. and Coelli, T.J. 1992. "Frontier Production. Technical Efficiency and Panel Data: With Applications to Paddy Farmers in
India". Journal of Productivity Analysis, 3: 153-169

Coelli, T.J. 1995. A Guide to Frontier, Version 4.1: A Computer program for Stochastic Frontier Production and Cost Function Estimation. Departement of econometrics, University og New England, Armidale, NSW, Australia

Nabilla. Ginting. dan Kesuma. 2014. Faktor-faktor yang Mempengaruhi Produksi dan Pendapatan Petani Jagung. Jurnal.usu.ac.id. 3(5)

Meeusem, W and J. Van den Broek. 1977. Efficiency Estimation from CobbDouglas Production Function with Compossed Error. International Economic Review. 18(2): 435-444 